\title{
A Multiplex Fluorescent PCR Assay in Molecular Breeding of Oilseed Rape
}

\author{
Katarzyna Mikolajczyk ${ }^{1}$, Iwona Bartkowiak-Broda ${ }^{1}$, Wieslawa Poplawska ${ }^{1}$, \\ Stanislaw Spasibionek ${ }^{1}$, Agnieszka Dobrzycka ${ }^{1}$ and Miroslawa Dabert ${ }^{2}$ \\ ${ }^{1}$ Plant Breeding and Acclimatization Institute - National Research Institute, \\ Research Division in Poznan, \\ ${ }^{2}$ Molecular Biology Techniques Laboratory, Faculty of Biology, \\ Adam Mickiewicz University in Poznan \\ Poland
}

\section{Introduction}

\subsection{Oilseed rape as an important oil crop}

Oilseed rape (Brassica napus L. var oleifera) is the second-most important oil crop in the world and it is a predominant one in Europe, with respect to seed oil production. The current seed yield of almost 60 metric tones (MT) makes above 13\% of the world oilseeds production. Due to oil crop market demands, rapeseed oil production permanently increases, not only for nutritional purposes but also for biodiesel production, according to the promoting the development of renewable energy European Commission Directives. The EU-27 countries are the most important producers of oilseed rape, with the leading contributors, such as Germany, France, Poland, Great Britain and the Czech Republic. The other important oilseed rape producers are: China, Canada, India, and Ukraine. B. napus is an allotetraploid (amphidiploid) species with an AACC genome $(2 n=38)$, which is derived from ancestral genomes of turnip, $B$. rapa syn. campestris $(\mathrm{AA}, 2 \mathrm{n}=20)$ and cabbage, $B$. oleracea $(C C, 2 n=18)$, according to the "Triangle of $U$ " (U, 1935). The B. napus haploid genome (AC) consists of 19 chromosomes deriving from $B$. rapa (fom A1 to A10) and from $B$. oleracea (C1 to C9) (http//www.brassica.info.resource/maps/lg-assignments.php).

Seeds of oilseed rape are a valuable source of oil ( $45 \%$ of seed mass) and protein $(20 \%)$. The discovery of the zero erucic acid (C22:1) lines in spring fodder variety Liho (Steffansson et al., 1961; Stefansson \& Hougen, 1964) and low glucosinolates content in Polish spring variety Bronowski (Downey \& Roebbelen, 1989; Krzymanski, 1968, 1970) were crucial milestones in oilseed rape breeding for seed yield quality. As a result of over fifty years of intensive breeding, superior cultivars with no erucic acid (C22:1) content in seed oil and with a very low glucosinolates content in seed meal have been developed and introduced into production. Those cultivars were named as double-low, double-zero (00), or canola (canola-type) ones. Oil of double-low cultivars is characterized by low content of saturated fatty acids and relatively high amount of C18 unsaturated fatty acids with 2:1 linoleic (C18:2) to linolenic (C18:3) acid ratio (Table 1). In addition, the presence of natural anti- 
oxidants (tocopherols) makes this oil an optimal and universal component of human diet used as salad oil, for salad dressing, short deep frying and margarine production (Snowdon et al., 2007). For nonfood purposes, canola oil may be used as a raw material for methyl ester (biodiesel) production, industrial lubricants, surface active agents for detergent and soap production, as well as for biodegradable plastics (Snowdon et al., 2007).

\begin{tabular}{ccccccccc}
\hline Type of oilseed rape & \multicolumn{7}{c}{ Fatty acid content [\%] } \\
\hline & Saturated & Oleic & Linoleic & Linolenic & Eicosenic & Erucic & other \\
\hline & $(\mathrm{C} 16: 0+\mathrm{C} 18: 0)$ & $(\mathrm{C} 18: 1)$ & $(\mathrm{C} 18: 2)$ & $(\mathrm{C} 18: 3)$ & $(\mathrm{C} 20: 1)$ & $(\mathrm{C} 22: 1)$ & \\
\hline High erucic/ & 4 & 11 & 12 & 9 & 8 & 52 & 4 \\
traditional & & & & & & & \\
00/ canola & 6 & 60 & 21 & 10 & 1 & 1 & 1 \\
Low linolenic & 6 & 61 & 28 & 3 & 1 & - & 1 \\
HOLL & 5 & 84 & 5 & 3 & 1 & - & 2 \\
\hline
\end{tabular}

Table 1. B. napus seed oil fatty acid composition (according to Wittkop et al., 2009)

\subsection{The main breeding goals for oilseed rape}

The C18:1 oleic acid is thermostable and appropriate for deep frying. The C18:2 linoleic acid with two double bonds provides nutritional benefits, whereas the C18:3 linolenic acid with three double bonds leads to instability and rapid oxidation. This reduces the shelf life of products (Barker et al., 2007, and references therein). Therefore, reduced level of polyunsaturated fatty acids, especially C18:3 linolenic acid, and increased content of monounsaturated C18:1 oleic acid provide higher oil stability. According to the demands of oil crop market, the development of high oleic (HO) and low linolenic (LL) cultivars is one of the major breeding goals. LL mutant of spring oilseed rape, M11 was obtained by ethyl methanesulfonate (EMS) treatment of the Canadian cultivar Oro (Rakow, 1973; Roebbelen \& Nitsch, 1975). Subsequently, low linolenic cultivars Stellar (Scarth et al., 1988) and Apollo (Scarth et al., 1995) were developed as a result of recombinant breeding of the M11 mutant line. Canola mutant inbred lines with high oleic $(\geq 75 \%)$ at the expense of polyunsaturated fatty acids $(\leq 6 \%)$ were developed by Auld et al. (1992). Another B. napus breeding line with modified fatty acid composition is the Dow AgroScience (DAS) proprietary HOLL (high oleic and low linolenic) mutant line DMS100 derived from the line AG019 (Hu et al., 2006, and references therein). New winter canola oilseed rape mutant lines were selected by Spasibionek (2003) and used for development of stable inbred lines with high oleic $(\geq 75 \%)$ and low linolenic $(\leq 3 \%)$ acid content (Spasibionek 2006; 2008). High oleic canola lines $(75 \%$ $85 \%$ ) were described by Falentin et al. (2007).

\subsection{Hybrid breeding methods and molecular markers for oilseed rape hybrid breeding programs}

In major rapeseed growing areas, hybrids represent an increasing proportion of the registered and cultivated varieties (Wittkop et al., 2009). In Europe, the oilseed rape hybrid breeding is based mainly on two male sterility systems: the ogura-INRA CMS (cytoplasmic male sterility) and the MSL-NPZ Lembke genic male sterility, whereas the ogura system is characterized by stable expression of male sterility in different genetic backgrounds and under different environmental conditions. 
In order to improve the poor agronomic value of new breeding materials with changed fatty acid composition developed by Spasibionek (2006) and to increase their seed and oil yield, they were introduced into new genetic background by crosses with high yielding cultivars and lines. Moreover, they were implemented into hybrid breeding, in which pollination controlling cytoplasmic male sterility (CMS) systems including male sterile cytoplasm and an appropriate restoring male fertility gene are used to produce F1 hybrid seeds. The new mutant lines were crossed with F1 hybrid components, i. e. the male-sterile and the restorer lines, in order to develop high-yielding single-cross hybrids with the desired traits.

An effective CMS system used for oilseed rape F1 hybrid seed production on commercial scale is the alloplasmic ogura radish CMS which completely ensures cross-pollination (Bartkowiak-Broda et al., 1979). It was originally found in radish (Raphanus sativus L.) by Ogura (1968) and transferred to B.oleracea and B.napus by interspecific crosses (Bannerot et al., 1974). Male-sterile B.napus cybrids were then produced throughout protoplast fusion (Pelletier et al., 1983) to generate male sterile lines with minor defects (Pelletier et al., 1987). Ogura CMS oilseed rape plants have phenotypically distinctive flowers with underdeveloped anthers. On molecular level, it is a result of the expression of mitochondrial locus orf 138 that is present in male sterile and absent in male fertile normal plant revealed by physical mapping studies (Bonhomme et al., 1992; Krishnasamy \& Makaroff, 1993). Primers specific for $5^{\prime}$ and $3^{\prime}$ ends of the orf138 nucleotide sequences (Krishnasamy \& Makaroff, 1993) were used for PCR-based identification of the ogura CMS cytoplasm during the fusion experiments of leaf protoplasts from fertile cabbage and cold-tolerant ogura CMS broccoli lines (Sigareva \& Earle, 1997). The orf138-specific primer pair was applied by our group for monitoring of the ogura CMS cytoplasm in B. napus breeding programs (Fig. 1, panel "CMS") (Mikolajczyk et al., 1998).

To obtain hybrid seeds, nuclear fertility restorer genes are required, which are present in native CMS-restorer systems. In turn, for identifying the $R f o$ restorer gene, the $1 \mathrm{~kb}$ SCAR (sequence characterized amplified region) marker, which we named as "C02" (Fig. 1, panel "Rfo") (Mikolajczyk et al, 2008) was developed by conversion of the OPC02 ${ }_{1150}$ RAPD (random amplified polymorphic DNA) marker tightly linked to the Rfo gene (Delourme et

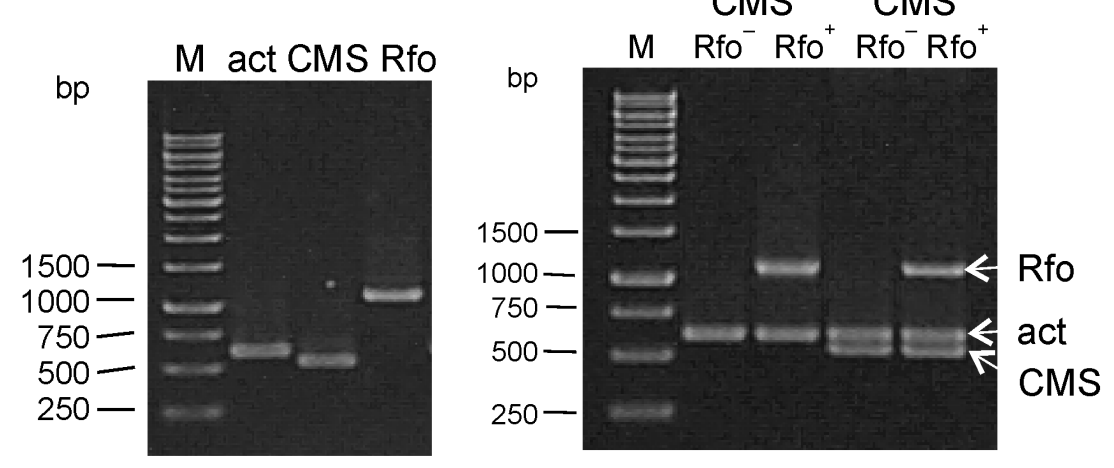

Fig. 1. Amplification of actin internal standard (act) and the $R f o$ and ogura CMS SCAR markers by separate (on the left) and multiplex (right) PCRs (Mikolajczyk et al., 2010a). 
al., 1994). Both SCAR markers were applied for identification of the ogura male-sterile cytoplasm and the Rfo gene in B. napus F hybrid components, F hybrids, as well as among the ogura CMS and Rfo restorer recombinants obtained as a result of crosses with high yielding and stress-resistant cultivars. The use of those markers proved to be very useful, due to phenotypic identity of F1 hybrids, $R f_{0}$ lines and $R f o$ recombinants, as well as the possibility of genotyping plants at the early stages of plant development.

To improve the effectiveness of the method and to reduce the costs, the multiplex PCR method was applied (Fig. 1, on the right) based on simultaneous amplification of both SCAR markers with an internal standard, a 600 bp conservative region of an actin 7 gene fragment (Figure 1, panel „act”) (Mikolajczyk et al., 2010a).

The low linolenic mutant genotypes were monitored with the use of the developed SNaPshot assay (Mikolajczyk et al., 2010b), detecting wild-type and mutant alleles of the $F A D 3$ desaturase genes in the AC allotetraploid genome of $B$. napus. The FAD3 genes encode for encoplasmic delta-15 linoleate desaturase responsible for desaturation of linoleic acid (C18:2) into linolenic acid. As a result of cloning and sequencing of FAD3 genes from wildtype and LL mutant B. napus plants, we reported two point mutations (BnaA.FAD3 and BnaC.FAD3) responsible for disruption of the FAD3 genes expression and function (Mikolajczyk et al., 2010b) in the new LL mutant rapeseed line (Spasibionek, 2006). One point mutation comprised a $\mathrm{C}$ to $\mathrm{T}$ transition in the mutant bnaA.fad3 gene leading to a possible Arg to Cys substitution. Another is a G to A transition in the $5^{\prime}$ donor splice site of the mutant bnaC.fad3 gene disrupting intron $6^{\text {th }}$ splicing. We developed genetic markers for monitoring FAD3 alleles in breeding programs. The detection of wild-type and mutant FAD3 alleles comprises two steps: independent PCR amplification of short SNP fragments and a detection of the SNPs based on microsequencing method (SNaPshot) with the use of allele-specific primers (Mikolajczyk et al., 2010b). The SNaPshot assay enabled precise and unambiguous detection of this allelic variability.

The developed multiplex PCR detecting the ogura CMS and the Rfo restorer gene along with the SNaPshot analysis for monitoring wild-type and mutant FAD3 alleles have been very useful for the precise determining of almost 700 of individual plants. This helped to select desired genotypes for further breeding of new high-yielding lines with changed fatty acid composition. With the use of molecular markers the selection process is more time- and costeffective.

Despite their usefulness, using both assays separately may generate errors. The analysis of a large number of individuals in independent assays increases the costs as well. To make the genotyping analysis more effective, we developed a new fluorescent multiplex PCR combined with SNaPshot detection for identification of the Rfo restorer gene, the ogura CMS, and the wild-type and mutant low linolenic genotypes in one assay. This new method is easy to adapt to high-throughput genotyping.

\section{Material and methods}

\subsection{Plant material}

The plant material used in this study were B. napus cultivars, recombinant and mutant lines, as well as the ogura CMS system F1 hybrids and F1 hybrid components, developed at the Plant Breeding and Acclimatization Institute - National Research Institute (NRI) in Poznan, 


\begin{tabular}{|c|c|c|c|c|c|}
\hline Cat. & Line & Parent(s) & Generation & $\begin{array}{l}\text { Number } \\
\text { of plants }\end{array}$ & $\begin{array}{l}\text { Owned } \\
\text { by/ }{ }^{*} \text { ref. }\end{array}$ \\
\hline 1. & $\begin{array}{l}\text { Recombinant inbred } \\
\text { lines }\end{array}$ & $\begin{array}{c}\text { LL M681 (PN1712) and Rfo } \\
\text { line PN 5-4 }\end{array}$ & $\begin{array}{l}\text { F3 (Rfo x LL } \\
\text { M681) }\end{array}$ & 10 & PBAI-NRI \\
\hline 2. & $\begin{array}{l}\text { Recombinant inbred } \\
\text { lines }\end{array}$ & $\begin{array}{c}\text { HO M10464 (PN1704), LL } \\
\text { M681 (PN1712) and Rfo } \\
\text { line PN 5-4 }\end{array}$ & $\begin{array}{c}\text { F3 (LL M681 x } \\
\text { HO M 10464) x } \\
\text { Rfo }\end{array}$ & 34 & PBAI-NRI \\
\hline 3. & Recombinant lines & $\begin{array}{l}\text { ogura CMS DH line 66-64- } \\
\text { 68/05 and DH LL M681 } \\
\text { (DH219) }\end{array}$ & $\begin{array}{c}\text { LL ogura CMS F1 } \\
\text { hybrid } \\
\text { component }\end{array}$ & 6 & PBAI-NRI \\
\hline 4. & Recombinant lines & $\begin{array}{l}\text { DH Rfo line PN544 and DH } \\
\text { LL M681 (DH219) }\end{array}$ & $\begin{array}{l}\text { LL } R f o \text { F1 hybrid } \\
\text { component }\end{array}$ & 7 & PBAI-NRI \\
\hline 5. & ogura CMS line & MS120 & multiplication & 1 & PBAI-NRI \\
\hline 6. & ogura CMS line & CMS PN66 & multiplication & 4 & PBAI-NRI \\
\hline 7. & Rfo DH line PN5/4 & BO 20-48 & $\mathrm{DH}$ & 1 & PBAI-NRI \\
\hline 8. & Rfo DH line PN492 & Rfo DH line PN17-5 & $\mathrm{DH}$ & 1 & PBAI-NRI \\
\hline 9. & $\begin{array}{l}\text { DH Rfo lines: } \\
\text { 337DHR2 and } \\
\text { 345DHR2 }\end{array}$ & no description & $\mathrm{DH}$ & 2 & PBAI-NRI \\
\hline 10. & Rfo line PN17/8 & Rfo line PN17-5 & multiplication & 1 & PBAI-NRI \\
\hline 11. & Rfo line R44/3i/07 & no description & multiplication & 1 & PBAI-NRI \\
\hline 12. & $\begin{array}{l}\text { HO Rfo recombinant } \\
\text { line PN1280 }\end{array}$ & $\begin{array}{c}\text { Rfo DH line PN544 and HO } \\
\text { line PN2185 }\end{array}$ & $\begin{array}{l}\text { Rfo PN544 x HO } \\
\text { PN2185 }\end{array}$ & 1 & PBAI-NRI \\
\hline 13. & $\begin{array}{c}\text { HOLL-type new } \\
\text { mutant DH line 321-2 }\end{array}$ & canola-type line PN5282 & mutagenesis & 1 & $\begin{array}{l}\text { *Spasibio } \\
\text { nek } 2008\end{array}$ \\
\hline 14. & $\begin{array}{l}\text { LL mutant DH lines: } \\
1044 / 2 \text { and } 1050 / 6\end{array}$ & LL M681 (PN1712) & DH & 2 & PBAI-NRI \\
\hline 15. & $\begin{array}{l}\text { HO mutant DH lines: } \\
1704 / 5 \text { and } 1704 / 60\end{array}$ & HO M10464 (PN 1704) & $\mathrm{DH}$ & 2 & PBAI-NRI \\
\hline 16. & $\begin{array}{c}\text { Recombinant line } \\
\text { A2/17 }\end{array}$ & $\begin{array}{l}\text { LL cultivar. Apollo and } \\
\text { canola-type line PN1775 }\end{array}$ & Apollo x PN1775 & 1 & PBAI-NRI \\
\hline 17. & $\begin{array}{c}\text { F1 hybrid cultivar. } \\
\text { Poznaniak }\end{array}$ & no description & F1 hybrid & 1 & $\begin{array}{c}\text { PBC } \\
\text { Strzelce- } \\
\text { Borowo } \\
\text { Ltd. }\end{array}$ \\
\hline 18. & F1 hybrid line PN600 & $\begin{array}{c}\text { CMS PN66 and Rfo DH } \\
\text { line PN5-4 }\end{array}$ & F1 hybrid & 1 & PBAI-NRI \\
\hline 19. & F1 hybrid line PN594 & $\begin{array}{l}\text { CMS PN64 and } R f o \text { DH } \\
\text { line PN17-5 }\end{array}$ & F1 hybrid & 1 & PBAI-NRI \\
\hline test-1 & $\begin{array}{c}\text { Rfo and ogura CMS } \\
\text { lines }\end{array}$ & no description & no description & 113 & $\begin{array}{l}\text { PBC } \\
\text { Smolice } \\
\text { Ltd. }\end{array}$ \\
\hline test-2 & $\begin{array}{c}\text { Rfo and ogura CMS } \\
\text { lines }\end{array}$ & no description & no description & 507 & $\begin{array}{l}\text { PBC } \\
\text { Strzelce } \\
\text { Ltd. }\end{array}$ \\
\hline
\end{tabular}

Table 2. Plant material used in this study. "Cat." - plant category; "PBAI-NRI" - Plant Breeding and Acclimatization Institute - National Research Institute, Research Division in Poznan, Poland; "PBC" - Plant Breeding Company. 
Poland and also at the Plant Breeding Company Ltd. Strzelce - Division at Borowo and at the Plant Breeding Company Ltd. Smolice - Division at Bakow, as it is presented in the Table 2. In total, 698 individual plants of different genetic background were analyzed.

\subsection{Molecular methods}

\subsubsection{DNA extraction}

Total genomic DNA was prepared from plant leaves, according to the CTAB extraction method (Doyle \& Doyle, 1990). For one sample, approximately 50-100 mg of young leaf tissue was put into a $1.5 \mathrm{ml}$ tube and ground thoroughly with a teflon pestle in $0.75 \mathrm{ml}$ of $7.5 \mathrm{pH}$ washing buffer containing: sorbitol $0.5 \mathrm{M}$, Tris $0.1 \mathrm{M}, \mathrm{Na}_{2}$ EDTA $0.07 \mathrm{M}$, and $\mathrm{Na}_{2} \mathrm{~S}_{2} \mathrm{O}_{3}$ $0.02 \mathrm{M}$. Then, following centrifugation of the suspension (at $12000 \times \mathrm{g}$ for $2 \mathrm{~min}$.), the supernatant was removed and the washed pellet was resuspended in $0.75 \mathrm{ml}$ of the CTAB buffer (8.0 pH Tris $\mathrm{HCl} 0.1 \mathrm{M}, \mathrm{NaCl} 1.4 \mathrm{M}$, CTAB 2\%, Na ${ }_{2}$ EDTA $0.02 \mathrm{M}$, PVP 40000 1\%) for $0.5 \mathrm{~h}$ extraction at $65{ }^{\circ} \mathrm{C}$. Subsequently, the equal volume of chlorophorm/octanol (24:1) solution was added and the suspension was shaken gently for $10 \mathrm{~min}$. The aqueous and organic phases were separated by centrifugation at $12000 \mathrm{xg}$ for $10 \mathrm{~min}$., then the aqueous phase was put into a fresh tube and nucleic acids were precipitated with $2 / 3$ volume of isoporpanol. After centrifugation, the supernatant was removed and the pellet was airdried. Then, $210 \mu \mathrm{l}$ of RNase A solution $(40 \mu \mathrm{g} / \mathrm{ml})$ was added and after $1 \mathrm{~h}$ of incubation at $37^{\circ} \mathrm{C}$, DNA was precipitated with $2 / 3$ volume of isopropanol in the presence of $0.9 \mathrm{M} \mathrm{NaCl}$. After centrifugation and removing of the supernatant, the pellet was washed with $70 \%$ etanol for $15 \mathrm{~min}$. Then, the ethanol was removed and the DNA sample was air-dried and resuspended in approximately $100 \mu \mathrm{l}$ of TE $(10 ; 0.1)$ buffer containing $8.0 \mathrm{pH}$ Tris $0.01 \mathrm{M}$ and $8.0 \mathrm{pH} \mathrm{Na} \mathrm{EDDT}^{\mathrm{E}} 0.0001 \mathrm{M}$. The obtained DNA sample contained about $10 \mathrm{ng}$ of DNA in 1 $\mu \mathrm{l}$ of solution.

\subsubsection{Fluorescent multiplex-PCR for Rfo and ogura CMS markers}

Primers for amplification of shortened fragments of the Rfo restorer, the ogura CMS, and B. napus actin 7 genes were developed based on nucleotide sequences of PCR products generated with primers designed previously for the multiplex PCR assay (Mikołajczyk et al., 2010a). In each primer pair, the forward primer was labeled at its $5^{\prime}$ end with the fluorescent dye 6-Carboxyl-X-Rhodamine (Rox) (see Table 3 for primer details). The lengths of the shortened amplicons varied from $97 \mathrm{bp}$ for ogura CMS to 115 for actin 7 (Table 3). PCR mixtures were prepared as described above, but the amplification was carried out by using the following parameters: $5 \mathrm{~min}$ at $95^{\circ} \mathrm{C} ; 29$ cycles of $30 \mathrm{~s}$ at $95^{\circ} \mathrm{C}, 90 \mathrm{~s}$ at $50^{\circ} \mathrm{C}$, and $30 \mathrm{~s}$ at $72^{\circ} \mathrm{C}$; and a final extension of $30 \mathrm{~min}$ at $65^{\circ} \mathrm{C}$. After the amplification, PCR products were cleaned with FAST alkaline phosphatase and exonuclease I (exoI) as described in the paragraph 2.2.3. The samples were diluted with $50 \mu \mathrm{l}$ of sterile deionized water (MQ; Millipore, USA) before capillary electrophoresis.

\subsubsection{PCR amplification of BnaA.FAD3 and BnaC.FAD3 gene fragments}

Target DNA fragments comprising polymorphic sites of BnaA.FAD3 and BnaC.FAD3 wildtype and mutant alleles were amplified in two independent reactions with the use of locusspecific PCR primer pairs (FAD3Af/FAD3Ar and FAD3Cf/FAD3Cr, respectively) developed 


\begin{tabular}{|c|c|c|c|c|c|c|}
\hline Primer & $\begin{array}{l}\text { Mod. } \\
\left(5^{\prime}\right)\end{array}$ & Sequence $\left(5^{\prime}-3^{\prime}\right)$ & Locus & $\begin{array}{l}\text { Product } \\
\text { (bp) }\end{array}$ & Use & Reference \\
\hline FAD3Af & & CATCATCATGGTCACGATGATAAGT & \multirow{2}{*}{ BnaA.FAD3 } & \multirow{2}{*}{189} & \multirow{4}{*}{$\begin{array}{l}\text { template } \\
\text { for SNaPshot } \\
\text { analysis } \\
\text { template } \\
\text { for SNaPshot } \\
\text { analysis }\end{array}$} & \multirow{2}{*}{$\begin{array}{l}\text { Mikolajczyk } \\
\text { et al. } 2010\end{array}$} \\
\hline FAD3Ar & & GAAGATCCCGTAATCTCTATCAAT & & & & \\
\hline shFAD3Cf & & CATCATCATGGTCACGATGATAAGC & \multirow{2}{*}{ BnaC.FAD3 } & \multirow{2}{*}{187} & & \multirow{2}{*}{$\begin{array}{l}\text { Mikolajczyk } \\
\text { et al. } 2010\end{array}$} \\
\hline $\mathrm{shFAD} 3 \mathrm{Cr}$ & & GAAGATCCCGTAATCTCTATCAAC & & & & \\
\hline Act-rox & \multirow[t]{2}{*}{ ROX } & CTCGACTCTGGTGATGGTGTG & \multirow{2}{*}{$\operatorname{actin} 7$} & \multirow{2}{*}{115} & \multirow{2}{*}{$\begin{array}{l}\text { internal PCR } \\
\text { control }\end{array}$} & \multirow{2}{*}{ this study } \\
\hline ActR5 & & TTCATTAGAGAATCCGTGAGA & & & & \\
\hline CMS-rox & ROX & TTCGAAAAAGGTAATCATTG & \multirow{2}{*}{$\begin{array}{c}\text { orf } 138 \\
\text { (ogura CMS) }\end{array}$} & \multirow{2}{*}{97} & \multirow{2}{*}{$\begin{array}{l}\text { ogura CMS } \\
\text { marker }\end{array}$} & \multirow{2}{*}{ this study } \\
\hline CMSp2 & & GTCGTTATCGACCTCGCAAGG & & & & \\
\hline Res-rox & $\mathrm{ROX}$ & TGTAACATAAGAAACGCTTGGT & \multirow{2}{*}{$R f_{0}$} & \multirow{2}{*}{107} & \multirow{2}{*}{$\begin{array}{l}\text { restorer gene } \\
\text { marker }\end{array}$} & \multirow{2}{*}{ this study } \\
\hline C02p3 & & TTGGCGCATCCTAAATTCAATC & & & & \\
\hline mutA-1f & (A) 6 & TGTACAATAATAGGAATGGAGTTATTTA & BnaA.FAD3 & 35 & $\begin{array}{l}\text { SNaPshot } \\
\text { analysis }\end{array}$ & $\begin{array}{l}\text { Mikolajczyk } \\
\text { et al. } 2010\end{array}$ \\
\hline mutC-45F & (A) 24 & TGCCTTGGTACAGAGGCAAG & BnaC.FAD3 & 45 & $\begin{array}{l}\text { SNaPshot } \\
\text { analysis }\end{array}$ & $\begin{array}{l}\text { Mikolajczyk } \\
\text { et al. } 2010\end{array}$ \\
\hline
\end{tabular}

Table 3. Oligonucleotides used in this study. "Mod." - 5'-terminal modification of the oligonucleotide; "Rox" - 6-Carboxyl-X-Rhodamine; "(A)6" - poly(A)-tail of 6 nucleotides; "(A)24" - poly(A)-tail of 24 nucleotides.

previously by Mikolajczyk et al. (2010b) for the analysis of splicing variant (see Table 3 for primer details). The PCR was carried out in a 96-well plate (Brandt, Wertheim, Germany) sealed with silicone compression mat (Axygen, Union City, CA, USA) in a reaction volume of $6 \mu \mathrm{l}$ containing $2.5 \mu \mathrm{l}$ of Type-it Microsatellite PCR Kit (Qiagen, Hilden, Germany), $0.2 \mathrm{mM}$ of each primer, and $1 \mu \mathrm{l}$ of DNA template (50-100 ng). Amplification was performed on Applied Biosystems thermal cyclers (Verity 96-Well, GeneAmp 9700, and 2720 TC) using the following PCR program: 1 cycle of $5 \mathrm{~min}$ at $95^{\circ} \mathrm{C}$, followed by 35 cycles of $30 \mathrm{~s}$ at $95^{\circ} \mathrm{C}$ and $90 \mathrm{~s}$ at $65^{\circ} \mathrm{C}$, and a final extension of $10 \mathrm{~min}$ at $65^{\circ} \mathrm{C}$. After the amplification, PCR products were cleaned with exonuclease I and alkaline phosphatase to remove free nucleotides and primers: $5 \mu \mathrm{l}$ containing $1 \mathrm{U}$ of FAST alkaline phosphatase and $2 \mathrm{U}$ of exoI (Fermentas, Vilnius, Lithuania) were combined with $6 \mu$ of the PCR product and incubated for $1 \mathrm{~h}$ at $37^{\circ} \mathrm{C}$, followed by denaturation step of $15 \mathrm{~min}$ at $80^{\circ} \mathrm{C}$.

\subsubsection{Detection of BnaA.FAD3 and BnaC.FAD3 alleles}

Both polymorphic sites were analysed independently by single-base primer extension reaction (microsequencing) with primers varying in length as described previously by Mikolajczyk et al. (2010b). The first oligonucleotide, mutA-1f (35 nt), was used for detection of alleles in the locus BnaA.FAD3, the second, mutC-45F (45 nt), was used for the locus BnaC.FAD3 (see Table 3 for primer details). Primer extension reaction was performed separately for each locus using $3 \mu \mathrm{l}$ exoI/FAST treated PCR product as template in a total volume of $10 \mu \mathrm{l}$ containing $2 \mu \mathrm{l}$ of the SNaPshot Ready Reaction Mix (Applied Biosystems, Foster City, CA, USA) and $0.2 \mathrm{mM}$ primer. The following microsequencing protocol was applied: 35 cycles of $10 \mathrm{~s}$ at $96^{\circ} \mathrm{C}, 5 \mathrm{~s}$ at $50^{\circ} \mathrm{C}$, and $30 \mathrm{~s}$ at $60^{\circ} \mathrm{C}$. After the reaction, $5 \mu \mathrm{l}$ containing $1 \mathrm{U}$ of FAST alkaline phosphatase was added to the each sample and incubated at $37^{\circ} \mathrm{C}$ for $15 \mathrm{~min}$. 


\begin{tabular}{|c|c|c|c|c|c|c|}
\hline & \multicolumn{3}{|c|}{ Reagent volumes $(\mu \mathrm{l})$ for } & \multicolumn{3}{|c|}{ PCR program } \\
\hline & 1 sample & 16 samples & 96 plate & $\begin{array}{l}\text { Temp. } \\
\left({ }^{\circ} \mathrm{C}\right)\end{array}$ & Time & Cycles \\
\hline \multicolumn{7}{|c|}{$\begin{array}{l}\text { 1. Fluorescent multiplex-PCR for Rfo and ogura CMS } \\
\text { markers. }\end{array}$} \\
\hline Type-it PCR Kit $(2 X)$ & 2.5 & 40 & 250 & 95 & $5 \min$ & \\
\hline Primer Act-rox $(10 \mu \mathrm{M})$ & 0.1 & 1.6 & 10 & 95 & $30 \mathrm{~s}$ & \\
\hline Primer ActR5 $(10 \mu \mathrm{M})$ & 0.1 & 1.6 & 10 & 50 & $90 \mathrm{~s}$ & 29 \\
\hline Primer CMS-rox $(10 \mu \mathrm{M})$ & 0.1 & 1.6 & 10 & 72 & $30 \mathrm{~s}$ & \\
\hline Primer CMSp2 $(10 \mu \mathrm{M})$ & 0.1 & 1.6 & 10 & 65 & $30 \mathrm{~min}$ & \\
\hline Primer Res-rox $(10 \mu \mathrm{M})$ & 0.1 & 1.6 & 10 & 4 & hold & \\
\hline Primer C02p3 $(10 \mu \mathrm{M})$ & 0.1 & 1.6 & 10 & & & \\
\hline MQ water & 1.9 & 32 & 190 & & & \\
\hline Total volume: & 5 & 81.6 & 500 & & & \\
\hline
\end{tabular}

Dispense $5 \mu \mathrm{l}$ of reaction mix into each well and add $1 \mu \mathrm{l}$ of genomic DNA. After the reaction, dilute with $50 \mu \mathrm{l}$ of MQ water and store at $4^{\circ} \mathrm{C}$ until use.

2. PCR amplification of BnaA.FAD3 and BnaC.FA3 gene fragments for SNaPshot analysis.

Type-it PCR Kit (2X)

FAD3Af or FAD3Cf $(10 \mu \mathrm{M})$

FAD3Ar or FAD3Cr $(10 \mu \mathrm{M})$

MQ water

Total volume:

2.5
0.1
0.1
2.3
5

\begin{tabular}{ll|l} 
& & \\
40 & 250 & 95 \\
1.6 & 10 & 95 \\
1.6 & 10 & 65 \\
38 & 230 & 65 \\
81.2 & 500 & 4
\end{tabular}

\begin{tabular}{|c|c|}
\hline 95 & $5 \mathrm{~min}$ \\
\hline 95 & $30 \mathrm{~s}$ \\
\hline 65 & $90 \mathrm{~s}$ \\
\hline 65 & $10 \mathrm{~min}$ \\
\hline 4 & hold \\
\hline
\end{tabular}

Dispense $5 \mu$ l of reaction mix into each well and add $1 \mu 1$ of genomic DNA.

3. Exonuclease I and alkaline phosphatase cleaning.

\begin{tabular}{llll|ll} 
FAST $(1 \mathrm{U} / \mu \mathrm{l})$ & 1 & 16 & 100 & 37 & $60 \mathrm{~min}$ \\
exoI $(20 \mathrm{U} / \mu \mathrm{l})$ & 0.1 & 1.7 & 10 & 80 & $15 \mathrm{~min}$ \\
exonuclease buffer $(10 \mathrm{X})$ & 0.5 & 8 & 50 & 4 & hold \\
MQ water & 3.4 & 55 & 340 & & \\
Total volume: & 5 & 80.7 & 500 &
\end{tabular}

Dispense $5 \mu 1$ of reaction mix into each well.

4. Detection of BnaA.FAD3 and BnaC.FAD alleles by the use of SNaPshot analysis.

$\begin{array}{llllll}\text { SNaPshot-mix (5X) } & 1 & 16 & 100 & 96 & 10 \mathrm{~s} \\ \text { Primer mutA-1f or mutC-45F }(10 \mu \mathrm{M}) & 0.2 & 3.2 & 20 & 96 & 10 \mathrm{~s} \\ \text { Sequencing Buffer }(5 \mathrm{X}) * & 1 & 16 & 100 & 50 & 5 \mathrm{~s} \\ \text { MQ water } & 4.8 & 80 & 480 & 60 & 30 \mathrm{~s} \\ \text { Total volume: } & 7 & 115.2 & 700 & 4 & \text { hold }\end{array}$

Dispense $7 \mu$ l of reaction mix into each well and add $3 \mu 1$ of PCR reaction from step 2 after exoI and FAST cleaning.

5. Alkaline phosphatase cleaning.

\begin{tabular}{llll|ll} 
FAST $(1 \mathrm{U} / \mu \mathrm{l})$ & 0.5 & 8 & 50 & 37 & $15 \mathrm{~min}$ \\
MQ water & 4.5 & 74 & 450 & 80 & $15 \mathrm{~min}$ \\
Total volume: & 5 & 82 & 500 & 4 & hold
\end{tabular}

Dispense $5 \mu$ l of reaction mix into each well.

6. Capillary electrophoresis.

HiDi formamide

GeneScan-120 LIZ

in 


\subsubsection{Capillary electrophoresis and genotype scoring}

The samples for electrophoresis containing $0.5 \mu \mathrm{l}$ of each microsequencing reaction, $0,5 \mu \mathrm{l}$ of water-diluted fluorescent multiplex-PCR, $0.2 \mu \mathrm{l}$ of GeneScan-120 LIZ size standard (Applied Biosystems), and $9 \mu \mathrm{l}$ of HiDi formamide (Applied Biosystems) were denatured for $5 \mathrm{~min}$ at $95^{\circ} \mathrm{C}$ and separated by capillary electrophoresis on an ABI Prism 3130XL Genetic Analyser (Applied Biosystems). Injection was performed at $1.2 \mathrm{kV}$ for $23 \mathrm{~s}$. Separation was carried out at $15 \mathrm{kV}, 60^{\circ} \mathrm{C}$ using $36-\mathrm{cm}$ capillaries containing POP7 polymer. Detection was performed using the dye set E5 in order to process the data from the 5 fluorescent dyes (dR110, dR6G, dTAMRA, dROX, and LIZ). The Rfo (Rfo), ogura CMS (CMS), and actin 7 (Act) gene fragments as well as the alleles of BnaA.FAD3 (A-wild, A-mut) and BnaC.FAD3 (C-wild, Cmut) were automatically visualized and scored using the GeneMapper 3.7 software (Applied Biosystems). The components of the reactions and the conditions concerning PCR amplifications, incubations, and capillary electrophoresis are presented in Table 4.

\section{Results}

We designed a multiplex fluorescent PCR test for the detection and identification of the $R f_{0}$ restorer gene, the ogura male sterile cytoplasm internally controlled by amplification of the actin 7 gene fragment of similar, but longer, length (Fig. 2, "Rfo", ,CMS”, "Act” in the upper panel). The fluorescently labeled PCR products and the specific oligonucleotide probe primers generated during SNaPshot analysis (Fig. 2, "A-wild”, "A-mut”, "C-wild”, "C-mut") were detected simultaneously in the same capillary during electrophoresis in the ABI Prism genetic analyzer. Using this method it is possible to detect all possible genotypes at genotyped loci. The following are presented as examples in Fig. 3: heterozygous at both FAD3 loci with CMS and $R f_{0}$ traits (sample D015), homozygous for the low linolenic mutant alleles at both FAD3 loci with CMS and $R f o$ traits (D011), homozygous for the mutant allele at BnaA.FAD3 locus and heterozygous at BnaC.FAD3 with CMS but without Rfo trait (Rob-10), heterozygous at BnaA.FAD3 locus and homozygous for the mutant allele at BnaC.FAD3 locus with $R f o$ but without CMS trait (D035), and the wild-type genotype, which is homozygous for the wild-type alleles at both FAD3 loci and has no CMS and Rfo traits (G001).

First, 190 plants belonging to 19 categories of recombinant lines (Table 2), previously phenotyped and/or genotyped, were used to test the accuracy and reproducibility of the new multiplex fluorescent assay. The results were compared with the previously analyzed genotypes (scored genotypes for selected plants as examples are presented in Table 5).

Using the new SNaPshot analysis in combination with the multiplex fluorescent assay, SNPs were detected in 95 plants analyzed previously for allelic variation in FAD3 genes. Among 190 SNP sites, 187 were scored accurately and in accordance with seed oil fatty acid composition determined by gas liquid chromatography (data not shown). Similarly, new fluorescent multiplex PCR was effective for detection of CMS and Rfo traits. Furthermore, the fluorescent assay was applied to the analysis of Rfo and ogura CMS lines included in breeding programs in plant breeding companies (test- 1 and test-2, Table 2). The results obtained from the analysis of 620 plants were consistent with the previous genotyping results obtained by conventional multiplex PCR (Fig. 3) and in accordance with breeders' predictions, revealing the fluorescent multiplex PCR assay as a sensitive tool for detection of CMS and $R f o$ traits in oilseed rape. 

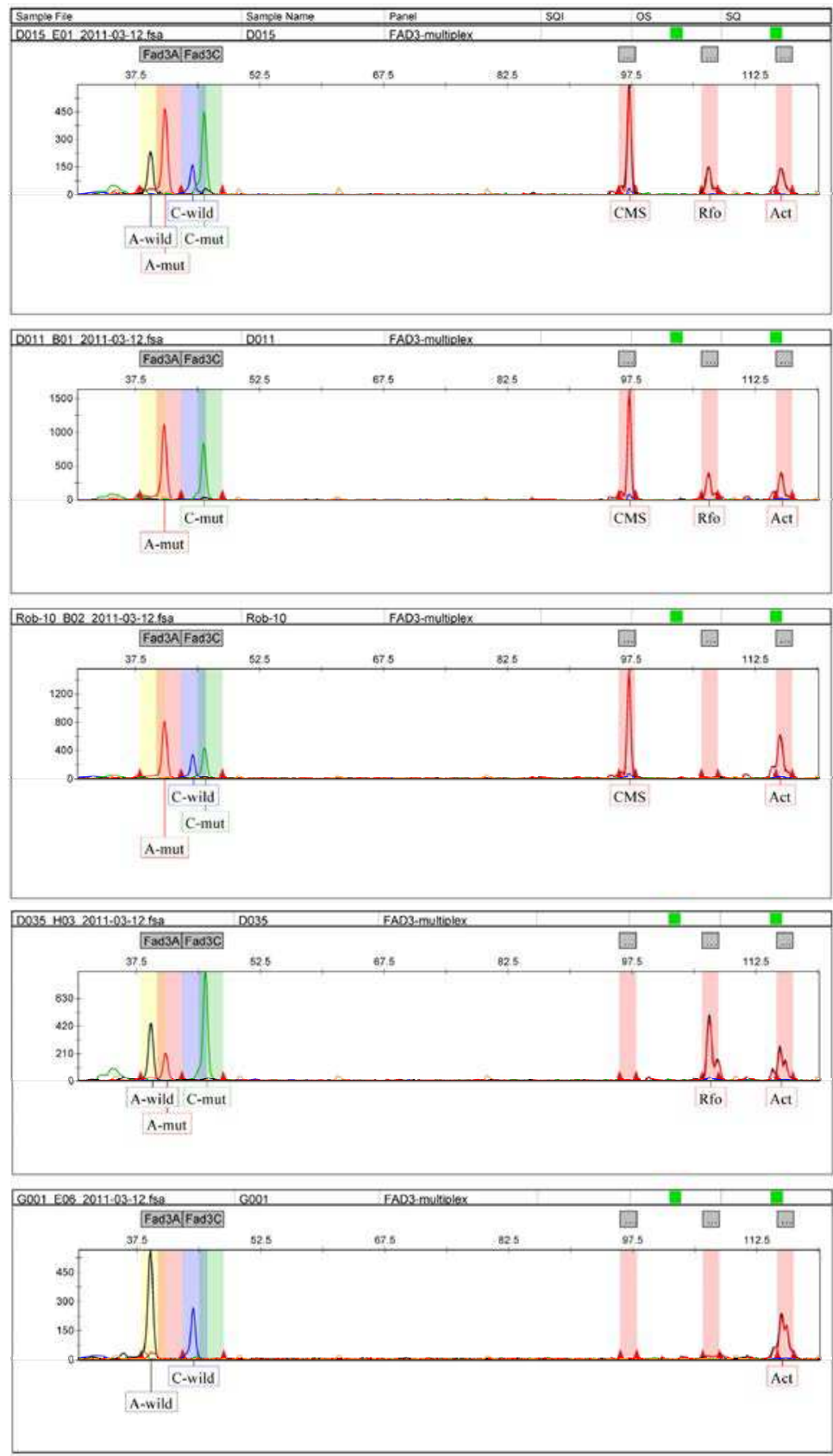

Fig. 2. The use of fluorescent labeled specific PCR products (red peaks on the right) together with specific oligonucleotide probe primers (black, red, green, and blue peaks on the left) generated during SNaPshot analysis. See text for details. 


\begin{tabular}{|c|c|c|c|c|c|c|c|c|c|c|c|c|}
\hline \multirow[b]{3}{*}{ Cat. } & \multirow[b]{3}{*}{ Plant } & \multicolumn{4}{|c|}{ Previously analyzed genotypes } & \multicolumn{7}{|c|}{ New multiplex fluorescent test } \\
\hline & & \multicolumn{2}{|c|}{ FAD3 genotype } & \multicolumn{2}{|c|}{ SCAR } & \multicolumn{2}{|c|}{ FAD3A } & \multicolumn{2}{|c|}{ FAD3C } & \multirow{2}{*}{$\begin{array}{c}\text { CMS } \\
\text { Allele } 1\end{array}$} & \multirow{2}{*}{$\begin{array}{c}\text { Rfo } \\
\text { Allele } 1\end{array}$} & \multirow{2}{*}{$\begin{array}{c}\text { Act } \\
\text { Allele 1 }\end{array}$} \\
\hline & & loc.A & loc.C & CMS & $\mathrm{C} 02$ & Allele 1 & Allele 2 & Allele 1 & Allele 2 & & & \\
\hline 5 & G006 & $\mathrm{AA}$ & $\mathrm{CC}$ & CMS & absent & A-wild & A-wild & C-wild & C-wild & CMS & absent & Act \\
\hline 6 & G030 & AA & CC & CMS & absent & A-wild & A-wild & C-wild & C-wild & CMS & absent & Act \\
\hline 6 & G039 & AA & $\mathrm{CC}$ & CMS & absent & A-wild & A-wild & C-wild & C-wild & CMS & absent & Act \\
\hline 7 & G031 & AA & $\mathrm{CC}$ & CMS & Rfo & A-wild & A-wild & C-wild & C-wild & CMS & Rfo & Act \\
\hline 8 & G048 & AA & $\mathrm{CC}$ & CMS & Rfo & A-wild & A-wild & C-wild & C-wild & CMS & Rfo & Act \\
\hline 9 & G007 & AA & $\mathrm{CC}$ & CMS & Rfo & A-wild & A-wild & C-wild & C-wild & CMS & Rfo & Act \\
\hline 12 & G055 & AA & $\mathrm{CC}$ & CMS & Rfo & A-wild & A-wild & C-wild & C-wild & CMS & Rfo & Act \\
\hline 13 & G001 & AA & $\mathrm{Cc}_{\mathrm{C}}$ & absent & absent & A-wild & A-wild & C-wild & C-wild & absent & absent & Act \\
\hline 14 & G002 & aа & $\mathrm{CC}$ & absent & absent & A-mut & A-mut & C-mut & C-mut & absent & absent & Act \\
\hline 14 & G003 & aa & $\mathrm{CC}$ & absent & absent & A-mut & A-mut & C-mut & C-mut & absent & absent & Act \\
\hline 15 & G004 & AA & CC & absent & absent & A-wild & A-wild & C-wild & C-wild & absent & absent & Act \\
\hline 16 & G009 & aa & $\mathrm{cC}$ & absent & absent & A-mut & A-mut & C-mut & C-mut & absent & absent & Act \\
\hline 17 & G045 & AA & $\mathrm{CC}$ & CMS & Rfo & A-wild & A-wild & C-wild & C-wild & CMS & Rfo & Act \\
\hline 18 & G032 & AA & $\mathrm{CC}$ & CMS & Rfo & A-wild & A-wild & C-wild & C-wild & CMS & Rfo & Act \\
\hline 19 & G043 & AA & $\mathrm{CC}$ & CMS & Rfo & A-wild & A-wild & C-wild & C-wild & CMS & Rfo & Act \\
\hline test-2 & W001 & AA & $\mathrm{CC}$ & CMS & Rfo & A-wild & A-wild & C-wild & C-wild & CMS & Rfo & Act \\
\hline test-2 & W084 & AA & $\mathrm{CC}$ & absent & absent & A-wild & A-wild & C-wild & C-wild & absent & absent & Act \\
\hline test-2 & Y008 & AA & $\mathrm{CC}$ & CMS & Rfo & A-wild & A-wild & C-wild & C-wild & CMS & Rfo & Act \\
\hline test-2 & Y065 & AA & CC & absent & Rfo & A-wild & A-wild & C-wild & C-wild & absent & Rfo & Act \\
\hline test-2 & Y066 & AA & $\mathrm{CC}$ & absent & absent & A-wild & A-wild & C-wild & C-wild & absent & absent & Act \\
\hline test-2 & Y073 & AA & CC & absent & Rfo & A-wild & A-wild & C-wild & C-wild & absent & Rfo & Act \\
\hline test-2 & Y075 & AA & $\mathrm{CC}$ & absent & absent & A-wild & A-wild & C-wild & C-wild & absent & absent & Act \\
\hline test-2 & Y076 & AA & $\mathrm{CC}$ & absent & Rfo & A-wild & A-wild & C-wild & C-wild & absent & Rfo & Act \\
\hline test-2 & Y077 & AA & $\mathrm{CC}$ & absent & Rfo & A-wild & A-wild & C-wild & C-wild & absent & Rfo & Act \\
\hline test-2 & Y090 & AA & $\mathrm{CC}$ & absent & Rfo & A-wild & A-wild & C-wild & C-wild & absent & Rfo & Act \\
\hline test-2 & Y116 & AA & $\mathrm{CC}$ & CMS & absent & A-wild & A-wild & C-wild & C-wild & CMS & absent & Act \\
\hline
\end{tabular}

Table 5. Comparison of plant genotyping results using separate SNaPshot analysis and conventional multiplex PCR (on the left) with the new multiplex fluorescent test (on the right). Only selected plants are presented as examples. "Cat." - plant category, "loc.A" alleles at locus BnaA.FAD3, "loc.C" - alleles at locus BnaC.FAD3, "A, C" - wild-type alleles, "a, c" - mutant alleles. See Table 2 for plant category details.

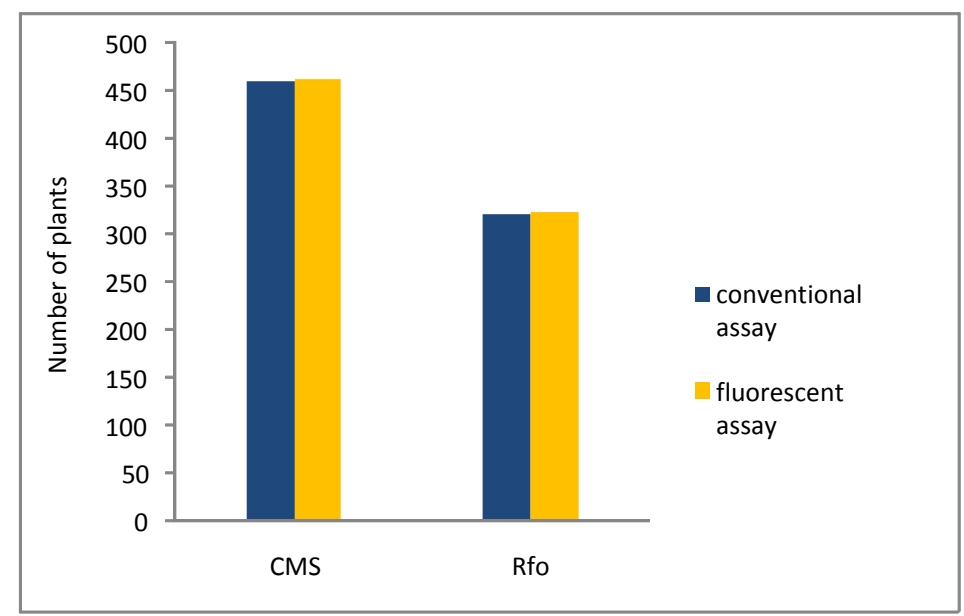

Fig. 3. Comparison of the number of CMS and $R f_{0}$ traits detected in analyzed plants using conventional (blue) and fluorescent (yellow) assays. 
1. PCR amplification $(\sim 2 \mathrm{~h})$
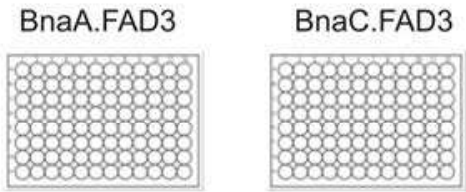

CMS+Rfo+Act

2. exol/FAST cleaning $(\sim 1.5 \mathrm{~h})$

3. SNaPshot analysis $(\sim 1.5 \mathrm{~h})$
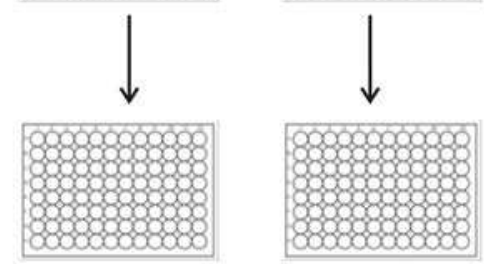

4. FAST cleaning $(\sim 0.5 \mathrm{~h})$

5. Plate for capillary electrophoresis $(\sim 0.5 \mathrm{~h})$

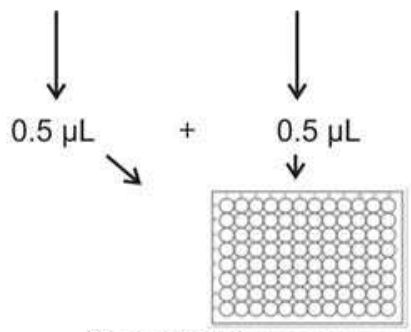

$9 \mu \mathrm{L} \mathrm{HiDi} \mathrm{Formamide}+0.2 \mu \mathrm{L} \mathrm{Liz120}$

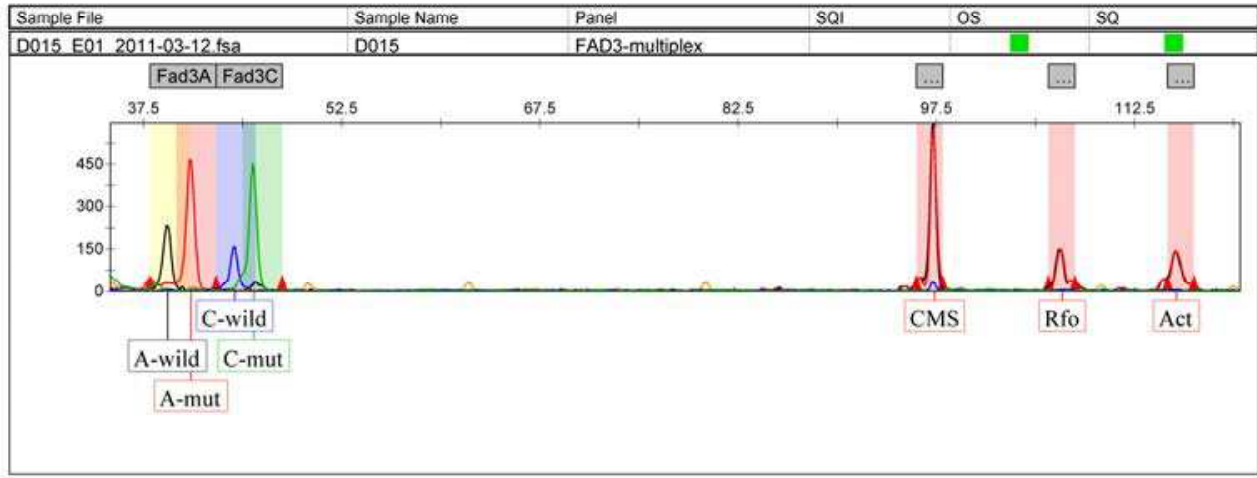

6. Capillary electrophoresis and automated allele scoring ( $\sim 2 \mathrm{~h}$ for 96 samples, $\mathrm{ABI} 3130 \mathrm{XL})$

Fig. 4. Multiplex fluorescent assay for detection of the $R f o$ restorer gene, the ogura male sterile cytoplasm and the low linolenic mutant genotypes in oilseed rape hybrid breeding. The assay can be performed within one working day.

\section{Discussion}

In the method described previously (Mikolajczyk et al., 2010b), much longer PCR products were used as templates for microsequencing in the search for allele-specific SNPs for the low linolenic mutant genotype of winter oilseed rape. The templates used in the former assay 
were generated using one locus-specific PCR primer (forward, from the 5'-end) while the second primer (reverse, from the $3^{\prime}$-end) was the same for both loci. The long length of the PCR products (1.1-1.34 kb) and non-specific reverse primer both could affect the efficiency of amplification. In fact, while assaying SNP polymorphism in plants from breeding experiments we found relatively lower amplification rate in case of the BnaA.FAD3 locus which could be correlated with the size of PCR product $(1.34 \mathrm{~kb})$. In the new assay, two short PCR (ca. 190 bp) amplicons are generated for each target by using locus-specific primer pairs. The level of fluorescence resulting from the amount of primer-extended products generated in the $\mathrm{SNaPshot}$ reaction shows that both loci are amplified at the same rate. The new amplification method is more effective, faster and very efficient.

A similar $\mathrm{G}$ to A substitution in the $5^{\prime}$ donor splice site associated with LL phenotype was detected in the mutant BnaC.fad3 of the canola mutant line DMS100 gene by Hu et al. (2006). The authors invented a method of this SNP detection based on hybridization-involving assay and real-time PCR technology. However, our new test combines cytoplasmic male sterility and low linolenic markers for the first time.

In plant studies, a multiplex fluorescent PCR method is applied for high throughput genetic mapping and measurement of the extent of diversity within and between cultivars using SSR (multiplex simple sequence repeat) markers. Up to now, identification of cytoplasm type and fertility restorer of rapeseed accessions for hybrid breeding has been performed using multiplex PCR method, followed by conventional gel electrophoresis. A simple multiplex PCR was applied by Zhao et al. (2010) to distinguish the existing common cytoplasm resources, Pol, Nap, Cam, and Ogu in rapeseed. In their test, four pairs of specific primers were used for the appropriate mitochondrial DNAs identification in addition to an internal control for the presence of nuclear DNA. According to our knowledge, the method presented in this chapter is the first assay combining the multiplex fluorescent PCR with $\mathrm{SNaPshot}$ analysis to be applied for plant molecular breeding.

\section{Conclusion}

The detection of the restorer gene, the ogura male sterile cytoplasm, and low linolenic mutant genotypes by multiplex fluorescence PCR combined with SNaPshot method is a practical alternative to classic methods of phenotype prediction. Starting with DNA, this method is fast with a turnaround time of 8 hours with mean reagent cost around \$2 per marker detected. Moreover, the assay could be extended by increasing or changing SNP and SCAR markers included in the test.

\section{Acknowledgments}

This work was partially supported by the Research Grant No. 4201401 (2007-2013) “Progress in plant production" sponsored by the Polish Ministry of Agriculture and Rural Development.

\section{References}

Auld, D. L., Heikken, M. K., Erickson, D. A., Sernyk, J. L., \& Romero, J. E. (1992). Rapeseed mutants with reduced levels of polyunsaturated fatty acids and increased levels of oleic acid. Crop Sci., Vol. 32, (3), pp. 657-662 
Bannerot H., Boulidard L., Cauderon Y., \& Tempe J. (1974). Cytoplasmic male sterility transfer from Raphanus to Brassica. Proceedings of EUCARPIA Meet. Crop. Sect. Crucirefae 25, pp. 52-54

Barker, G. C., Larson, T. R., Graham, I. A., Lynn, J. R., \& Graham, J. K. (2007). Novel Insights into Seed Fatty Acid Synthesis and Modification Pathways from Genetic Diversity and Quantitative Trait Loci Analysis of the Brassica C Genome ${ }^{1[\mathrm{OA}]}$. Plant Physiology, Vol. 144, (4), pp. 1827-1842

Bartkowiak-Broda, I., Rouselle P., \& Renard M. (1979). Investigations of two kinds of cytoplasmic male sterility in rapeseed (Brassica napus L.). Genetica Polonica, Vol. 20, (4), pp. 487-497

Bonhomme, S., Budar F., Lancelin, D., Small, I., Defrance, M.-C., \& Pelletier G. (1992). Sequence and transcript analysis of the Nco2.5 Ogura-specific fragment correlated with cytoplasmic male sterility in Brassica hybrids. Mol. Gen. Genet., Vol. 235, (2/3), pp. 340-348

Delourme, R., Bouchereau, A., Hubert, N., Renard, M., \& Landry, B.S. (1994). Identification of RAPD markers linked to a fertility restorer gene for the Ogura radish cytoplasmic male sterility of rapeseed (Brassica napus L.). Theor Appl Genet, Vol. 88, (6/7), pp. 741-748

Doyle, J.J., \& Doyle, J.L. (1990). Isolation of plant DNA from fresh tissue. Focus, Vol. 12, pp. 13-15

Downey, R.K., \& Roebbelen G. (1989). Brassica species, In: Oil Crops of the World, G. Roebbelen, R. K. Downey \& A. Ashri, (Eds.), pp. 339-382, McGraw-Hill Publishing Co., New York

Falentin, C., Brégeon, M., Lucas, M. O., Deschamps, M., Leprince, F., Fournier, M. T., Delourme, R., \& Renard M. (2007). Identification of fad2 mutations and development of allele-specific markers for high oleic acid content in rapeseed (Brassica napus L.), Proceedings of the $12^{\text {th }}$ International Rapeseed Congress, vol. II Biotechnology, pp. 117-119, Wuhan, China, March 2007

$\mathrm{Hu}$, X., Sullivan, M.L., Gupta, M., \& Thompson S.A. (2006). Mapping of the loci controlling oleic and linolenic acid contents and development of fad2 and fad3 allele-specific markers in canola (Brassica napus L.) Theor Appl Genet, Vol. 113, (3), pp. 497-507

Krishnasamy, S., \& Makaroff, C.A. (1993). Characterization of the radish mitochondrial orfB locus: possible relationship with male sterility in Ogura radish. Curr. Genet., Vol. 24, (1/ 2), pp. 156-163

Krzymanski, J. (1968). Variation in thioglucosides in rapeseed meal (Brassica napus). Meeting of the Associate Commitees of National Research Council in Plant Breeding. Winnipeg, Manitoba, Canada 20.02.1968

Krzymanski, J. (1970). Genetyczne mozliwości ulepszania skladu chemicznego nasion rzepaku ozimego./ Changes of genetical improvement of chemical composition of winter oilseed rape (Brassica napus) seeds (In Polish). Hodowla Roslin Aklimatyzacja $i$ Nasiennictwo, Vol. 14, (2), pp. 95-133

Mikolajczyk, K., Matuszczak, M., Pietka, T., Bartkowiak-Broda, I., \& Krzymanski J. (1998). The use of DNA markers for hybrid component analysis (in Polish, abstract in English). Rośliny Oleiste - Oilseed Crops, Vol. XIX (2), pp. 463-471

Mikolajczyk, K., Dabert, M., Nowakowska, J., Podkowinski, J., Poplawska, W., \& Bartkowiak-Broda I. (2008). Conversion of the RAPD OPC $02_{1150}$ marker of the Rfo 
restorer gene into a SCAR marker for rapid selection of oilseed rape. Plant Breeding, Vol. 127, (6), pp. 647-649

Mikolajczyk, K., Dobrzycka, A., Podkowinski, J., Poplawska W., Spasibionek S., \& Bartkowiak-Broda, I. (2010a). A multiplex PCR assai for identification of the ogura male sterile cytoplazm and the $R f o$ restorer gene among oilseed rape breeding forms. Rosliny Oleiste - Oilseed Crops, Vol. XXXI, (2), pp. 201-210

Mikolajczyk, K., Dabert, M., Karlowski, W. M., Spasibionek, S., Nowakowska, J., CegielskaTaras, T., \& Bartkowiak-Broda I. (2010b). Allele-specific SNP markers for the new low linolenic mutant genotype of winter oilseed rape. Plant Breeding, Vol. 129, (5), pp. 502-507

Ogura, H. (1968). Studies on the new male sterility in Japanese radish, with special references to the utilisation of this sterility towards the practical raising of hybrid seeds. Mem. Fac. Agr. Kogoshima Univ., Vol. 6, pp. 39-78

Pelletier, G., Primard, C., Vedel, F., Chetrit, P., Remy, R., Rousselle, P., \& Renard M. (1983). Intergeneric cytoplasm hybridization in Cruciferae by protoplast fusion. Mol. Gen. Genet., Vol. 191, pp. 244-250

Pelletier, G., Primard, C., Vede,l F., Chetrit, P., Renard, M., Pellan-Delourme, R., \& Mesquida J. (1987). Molecular phenotype and genetic characterization of mitochondrial recombinants in rapeseed. Proceedings of the $7^{\text {th }}$ International Rapeseed Congress, Poznan, Poland, pp. 113-118

Rakow, G. (1973). Selektion auf Linol- und Linolensaeuregehalt in Rapssamen nach mutagener Behandlung. Z. Pflanzenzuechtg, Vol. 69, pp. 62-82

Roebbelen, G., \& Nitsch, A. (1975). Genetical and physiological investigations on mutants for polynoic fatty acids in rapeseed, Brassica napus L. Z. Pflanzenzuechtg, Vol. 75, pp. 93-105

Scarth, R., McVetty, P.B.E., Rimme,r S.R., \& Stefansson, B.R. (1988). 'Stellar' low linolenichigh linoleic acid summer rape. Can. J. Plant Sci., Vol. 68 (April 1988), pp. 509-511

Scarth, R., Rimmer, S.R., \& McVetty, P.B.E. (1995). Apollo low linolenic acid summer rape. Can. J. Plant Sci. 75, (1): 203-204

Sigareva M.A., Earle E.D. (1997) Direct transfer of a cold-tolerant Ogura male-sterile cytoplasm into cabbage (Brassica oleracea ssp. capitata) via protoplast fusion. Theor. Appl. Genet., Vol. 94, (2), pp. 213-220

Snowdon, R., Luehs, W., \& Friedt, W. (2007). Oilseed rape, In: Genome Mapping and Molecular Breeding in Plants, K. Chittaranjan, (Ed.), 55-114, Springer-Verlag Berlin Heidelberg, ISBN-13 978-3-540-34387-5, Leipzig, Germany

Spasibionek, S. (2006). New mutants of winter rapeseed (Brassica napus L.) with changed fatty acid composition. Plant Breding, Vol. 125, (3), pp. 259-267

Spasibionek, S., Krzymański, J., \& Bartkowiak-Broda, I. (2003). Mutants of Brassica napus with changed fatty acids composition. Proceedings of the $11^{\text {th }}$ International Rapeseed Congress, pp. 221-224, Copenhagen, Denmark, July 2003.

Spasibionek, S. (2008). Variability of fatty acid composition in seed oil of winter rapeseed (Brassica napus L.) developed using mutagenesis. Rośliny Oleiste - Oilseed Crops, Vol. XXIX, (2), pp. 161-168

Stefansson, B.R. Hougen, F.W., \& Downey, R.K. (1961). Note on the isolation of rape plants with seed oil free from erucic acid. Can. J. Plant Sci., Vol. 41, pp. 218-219 
Stefansson, B.R., \& Hougen, F.W. (1964). Selection of rape plants (Brassica napus) with seed oil practically free of erucic acid. Can. J. Plant Sci., Vol. 44, (4), pp. 359-364

U, N. (1935). Genome analysis in Brassica with special reference to the experimental formation of B. napus peculiar mode of fertilization. Jpn. J. Bot., Vol. 7, pp. 389-452

Wittkop, B., Snowdon, R., Friedt, W. (2009). Status and perspectives of breeding for enhanced yield and quality of oilseed crops for Europe. Euphytica, Vol. 170, (1/2), pp. 131-140

Zhao, H. X., Li, Z. J., Hu, S. W., Sun, G. L., Chang, J. .J, \& Zhang, Z. H. (2010). Identification of cytoplasm types in rapeseed (Brassica napus L.) accessions by a multiplex PCR assay. Theor Appl Genet, Vol. 121, (4), pp. 643-50 


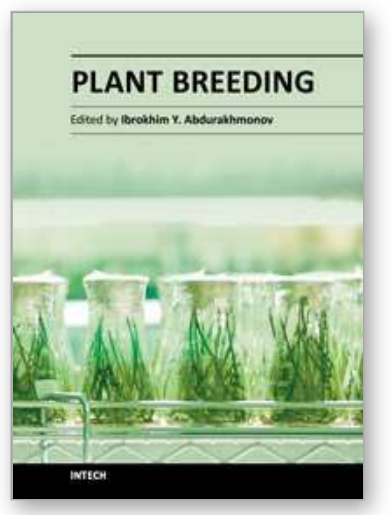

\author{
Plant Breeding \\ Edited by Dr. Ibrokhim Abdurakhmonov
}

ISBN 978-953-307-932-5

Hard cover, 352 pages

Publisher InTech

Published online 11, January, 2012

Published in print edition January, 2012

Modern plant breeding is considered a discipline originating from the science of genetics. It is a complex subject, involving the use of many interdisciplinary modern sciences and technologies that became art, science and business. Revolutionary developments in plant genetics and genomics and coupling plant "omics" achievements with advances on computer science and informatics, as well as laboratory robotics further resulted in unprecedented developments in modern plant breeding, enriching the traditional breeding practices with precise, fast, efficient and cost-effective breeding tools and approaches. The objective of this Plant Breeding book is to present some of the recent advances of 21 st century plant breeding, exemplifying novel views, approaches, research efforts, achievements, challenges and perspectives in breeding of some crop species. The book chapters have presented the latest advances and comprehensive information on selected topics that will enhance the reader's knowledge of contemporary plant breeding.

\title{
How to reference
}

In order to correctly reference this scholarly work, feel free to copy and paste the following:

Katarzyna Mikolajczyk, Iwona Bartkowiak-Broda, Wieslawa Poplawska, Stanislaw Spasibionek, Agnieszka Dobrzycka and Miroslawa Dabert (2012). A Multiplex Fluorescent PCR Assay in Molecular Breeding of Oilseed Rape, Plant Breeding, Dr. Ibrokhim Abdurakhmonov (Ed.), ISBN: 978-953-307-932-5, InTech, Available from: http://www.intechopen.com/books/plant-breeding/a-multiplex-fluorescent-pcr-assay-in-molecular-breeding-ofoilseed-rape

\section{INTECH}

open science | open minds

\section{InTech Europe}

University Campus STeP Ri

Slavka Krautzeka 83/A

51000 Rijeka, Croatia

Phone: +385 (51) 770447

Fax: +385 (51) 686166

www.intechopen.com

\section{InTech China}

Unit 405, Office Block, Hotel Equatorial Shanghai

No.65, Yan An Road (West), Shanghai, 200040, China

中国上海市延安西路65号上海国际贵都大饭店办公楼405单元

Phone: +86-21-62489820

Fax: $+86-21-62489821$ 
(C) 2012 The Author(s). Licensee IntechOpen. This is an open access article distributed under the terms of the Creative Commons Attribution 3.0 License, which permits unrestricted use, distribution, and reproduction in any medium, provided the original work is properly cited. 